\title{
HUBUNGAN KUALITAS PELAYANAN ANTENATAL DENGAN TINGKAT KEPUASAN IBU HAMIL
}

\author{
Correlation of Quality of Antenatal Care with Pregnancy Women Satisfaction Rates
}

\author{
Ni Putu Mita Rahayu ${ }^{1}$, Ni Ketut Citrawati ${ }^{2}$, Dewa Gede Juliawan ${ }^{3}$ \\ ${ }^{1}$ Mahasiswa Program Studi S1 Keperawatan, STIKes Wira Medika Bali, Denpasar, Bali, Indonesia \\ ${ }^{2}$ Departemen Keperawatan Maternitas, STIKes Wira Medika Bali, Denpasar, Bali, Indonesia \\ ${ }^{3}$ Departemen Keperawatan Medikal Bedah, STIKes Wira Medika Bali, Denpasar, Bali, Indonesia \\ Korespondensi: mitarahayu93@yahoo.co.id
}

\begin{abstract}
ABSTRAK
AKI (angka kematian ibu) yaitu jumlah kematian ibu selama masa kehamilan, persalinan dan nifas. Kematian ini disebabkan oleh kehamilan, persalinan, dan nifas. Pada dasarnya penyebab kematian ibu dikarenakan kurang melakukan pemeriksaan pada saat hamil dan tidak rutin melakukan kunjungan ANC (antenatal care).Hal ini sebagai penyebab ibu hamil beresiko mengalami perdarahan dan pre eksklamsia yang menyebakan kematian pada ibu atau bayi. Tujuan Penelitian: Penelitian ini bertujuan untuk mengetahui hubungan antara kualitas pelayanan ANC dengan tingkat kepuasan ibu hamil. Design penelitian yang digunakan yaitu cross-sectional. Sampel yang digunakan sebanyak 86 ibu hamil. Sampel diambil dengan teknik Non probability sampling yaitu Consecutive sampling, kemudian dianalisis denganuji rank spearman. Hasil penelitian menunjukkan bahwa hubungan antara kualitas pelayanan ANC dengan tingkat kepuasan ibu hamil $\mathrm{P}$-value $=0,000$ yang berarti ada hubungan antara kualitas pelayanan ANC dengan tingkat kepuasan ibu hamil. Kualitas pelayanan ANC sangat berhubungan dengan tingkatan kepuasan ibu hamil saat melakukan kunjungan.Hasil penelitian ini bisa dijadikan masukan bagi tenaga kesehatan dan pelayanan kesehatanuntuk meningkatkan kualitas pelayanan antenatal sesuai SOP.
\end{abstract}

Kata kunci: kualitas pelayanan ANC; tingkat kepuasan ibu hamil

\begin{abstract}
AKI (maternal mortality rate) is the number of maternal deaths during pregnancy, childbirth and the puerperium. This death is caused by pregnancy, childbirth, and the puerperium. Basically the cause of maternal death due to lack of examination during pregnancy and not routinely make ANC visits (antenatal care). This is the cause of pregnant women at risk of bleeding and pre-eclampsia which causes death to the mother or baby. Research Objectives: This study aims to determine the relationship between the quality of ANC services with the level of satisfaction of pregnant women. The research design used is cross-sectional. The sample used was 86 pregnant women. Samples were taken with a Non probability sampling technique that is Consecutive sampling, then analyzed by Spearman rank test. The results showed that the relationship between the quality of ANC services with the level of satisfaction of pregnant women $P$-value $=0,000$ which means there is a relationship between the quality of ANC services with the level of satisfaction of pregnant women. The quality of ANC services is closely related to the level of satisfaction of pregnant women during a visit. The results of this study can be used as input for health workers and health services to improve the quality of antenatal care according to SOP.
\end{abstract}

Keywords: ANC service quality; the level of satisfaction of pregnant women 
Ni Putu Mita Rahayu: Hubungan Kualitas Pelayanan ANC dengan Tingkat Kepuasan Ibu Hamil di Wilayah Kerja Puskesmas Kuta Selatan

\section{PENDAHULUAN}

Sustainable Development Goals (SDGs) adalah kelanjutan dari global goals Milenium Development Goals (MDGs) yang berakhir tahun 2015. Menurut kemenkes RI dalam program SDGs bahwa target system kesehatan nasional yaitu pada goals ke 3 menerangkan bahwa pada 2030, mengurangi angka kematian ibu hingga di bawah 70 per 100.000 kelahiran hidup. Keberhasilan upaya peningkatan kesehatan ibu, di antaranya dapat dilihat dari indicator Angka Kematian Ibu (AKI). AKI adalah jumlah kematian ibu selama masa kehamilan, persalinan dan nifas yang disebabkan oleh kehamilan, persalinan, dan nifas atau pengelolaannya tetapi bukan karena sebab-sebab lain seperti kecelakaan, terjatuh di setiap 100.000 kelahiran hidup. SDKI tahun 2012 menunjukkan peningkatan AKI yang signifikan yaitu menjadi 359 kematian ibu per 100.000 kelahiran hidup. AKI kembali menunjukkan penurunan menjadi 305 kematian ibu per 100.000 kelahiran hidup berdasarkan hasil Survei Penduduk Antar Sensus (SUPAS) 2015 (Aeroh, 2017).

Angka kematian ibu (AKI) merupakan salah satu indikator kesehatan nasional dan merupakan target SDGs 2030 dimana AKI menurun hingga 70 per 100.000 kelahiran hidup (Bappenas, 2013). Di tahun 2016 AKI di Indonesia masih sangat tinggi yaitu mencapai 359 per 100.000 kelahiran hidup, angka tersebut menduduki peringkat pertama di Asia Tenggara (Rafikasari 2017 dalam Handayani, 2019). Pada dasarnya penyebab kematian ibu dikarenakan kurang melakukan pemeriksaan pada saat hamil (antenatal care) (Lestari 2017 dalam, Handayani 2019).

Pelayanan antenatal adalah pemeriksaan yang dilakukan untuk memeriksa keadaan ibu hamil dan janinnya secara berkala, yang diikuti upaya koreksi terhadap penyimpangan yang ditemukan (Haposanita, 2014). Pelayanan antenatal yang dilakukan secara teratur dan komprehensif dapat mendeteksi secara dini kelainan dan risiko yang mungkin timbul selama kehamilan, sehingga kelainan dan risiko tersebut dapat diatasi dengan cepat dan tepat (Marniyati dkk, 2016).

Kunjungan ANC yang tidak rutin menyebabkan ibu hamil beresiko mengalami perdarahan dan pre eksklamsia yang menyebabkan kematian pada ibu atau bayi. Sebagai mana yang diketahui bahwa pendarahan dan pre eklamsia bisa dapat dicegah sedini mungkin apabila ibu hamil rutin melakukan pemeriksaan kehamilan atau antenatal care sehingga informasi dan pengetahuan tentang tanda bahaya kehamilan dapat diketahui.

Pemerintah menetapkan, bahwa pelayanan antenatal yang baik memenuhi asuhan standar minimal "14T" yaitu timbang dan ukur tinggi badan, ukur tekanan darah, tinggi fundus uteri, tetanus toxoid, tablet $\mathrm{Fe}$, tes PMS, pemeriksaan $\mathrm{HB}$, temu wicara, perawatan payudara, pemeliharaan tingkat kebugaran atau senam hamil, pemeriksaan protein urine atas indikasi, pemeriksaan reduksi urine atas indikasi, pemberian terapi kapsul yodium dan pemberian terapi anti malaria (Rukiyah 2014 dalam, Rufaidah 2019).

Menurut Riset Kesehatan Dasar tahun 2018, hampir seluruh ibu di Indonesia sudah melakukan pemeriksaan kehamilan. Cakupan k1 bervariasi dengan rentang antara 63,5\% di Sulawesi Tenggara dan $89,8 \%$ di Bali. Namun untuk cakupan ANC 4 kali, Bali mengalami penurunan sebanyak $79 \%$ dan tertinggi di Yogyakarta 92,2 \% Selisih k1 dan k4 menunjukkan adanya kehamilan yang tidak optimal mendapat pelayanan ANC sehingga tidak melanjutkan ANC sesuai standar minimal (k4).

Berdasarkan dari data Dinas Kesehatan Provinsi Bali tahun 2017 kunjungan ANC tertinggi di Kabupaten Klungkung dengan jumlah kunjungan K1 sebanyak 109,9\% dan K4 sebanyak $104,50 \%$, sedangkan kunjungan ANC terendah di Kabupaten Badung dengan kunjungan K1 sebanyak 85,1\% dan K4 sebanyak 75,64\%. Dinas Kesehatan Kabupaten Badung tahun 2017 menunjukkan bahwa Puskesmas Kuta II mendapat kunjungan ANC tertinggi dengan k1 sebanyak $100 \%$ dan $\mathrm{k} 4$ sebanyak $98,17 \%$, Puskesmas dengan kunjungan ANC terendah yaitu di Puskesmas Kuta 
Selatan dengan k1 sebanyak $61,98 \%$ dan k4 sebanyak 53,57\%.

Terdapat lima kriteria yang menentukan kualitas suatu pelayanan yaitu: Reliability (kemampuan), yaitu kemampuan untuk melakukan pelayanan sesuai yang dijanjikan, akurat dan memuaskan. Responsiveness (ketanggapan), yaitu kemampuan untuk menolong pelanggan untuk melayani dengan baik Assurance (jaminan), yaitu pengetahuan kesopanan petugas serta sifatnya yang dapat dipercaya. Empathy (perhatian), yaitu rasa peduli untuk memberikan perhatian secara individual kepada pelanggan, memahami kebutuhan pelanggan serta kemudahan untuk dihubungi. Tangibles (bukti langsung), yaitu meliputi fasilitas fisik, perlengkapan karyawan dan sarana komunikasi (Haposanita, 2014).

Pelayanan antenatal akan menyebabkan ibu hamil yang berkunjung merasa puas. Kepuasan adalah tingkat perasaan seseorang setelah membandingkan kinerja atau hasil yang dirasakan dengan harapannya. Apabila kinerja atau keterampilan tenaga kesehatan dibawah harapan maka pasien akan kecewa, apabila kinerja atau keterampilan sesuai dengan harapan, maka pasien akan puas. Dampak ketidakpuasan pasien akan memperlemah hubungan antara pasien dengan bidan,oleh karena itu diperlukan suatu solusi pemecahan masalah sehingga dalam memberikan pelayanan kebidanan, semua pasien akan merasa puas (Azwar 2007 dalam, Melay 2013).

Berdasarkan hasil studi pendahuluan yang dilakukan pada tanggal 4 Februari 2019 di Puskesmas Kuta Selatan. Pelayanan ANC yang ada di puskemas memberikan pelayanan dari hari senin sampai hari kamis dengan jumlah kunjungan rata-rata per hari 15-20 ibu hamil, untuk hari jumat puskesmas melaksanakan senam untuk ibu hamil. Berdasarkan hasil wawancara $10 \mathrm{ibu}$ hamil yang melakukan pemeriksaan ANC di Puskesmas Kuta Selatan dengan menggunakan indikator faktor-faktor yang mempengaruhi kepuasan didapatkan 3 orang mengatakan cukup puas dengan pelayanan di Puskesmas yang telah diberikan, sedangkan 7 orang mengatakan kurang puas dikarenakan belum optimalnya kunjungan rumah oleh petugas puskesmas, antrean yang cukup panjang dan kurangnya waktu petugas kesehatan dalam menyediakan waktu untuk mendengarkan keluhan pada ibu hamil. Berdasarkan uraian diatas, peneliti tertarik untuk melakukan penelitian tentang "Hubungan Kualitas Pelayanan ANC Dengan Tingkat Kepuasan Ibu Hamil Di Wilayah Kerja Puskesmas Kuta Selatan".

\section{TUJUAN PENELITIAN}

Penelitian ini bertujuan untuk mengetahui Hubungan Kualitas Pelayanan ANC Dengan Tingkat Kepuasan Ibu Hamil Di Wilayah Kerja Puskesmas Kuta Selatan.

\section{METEDOLOGI PENELITIAN}

Desain

Penelitian ini adalah penelitian korelasi dengan menggunakan deskriptif korelasi pendekatan cross sectional.

\section{Populasi dan Sampel}

Populasi dalam penelitian ini adalah ibu hamil yang melakukan pemeriksaan ANC. Sampel pada penelitian ini diambil sesuai dengan kriteria inklusi dan eksklusi dengan jumlah sampel 86 orang yang diambil dengan Consecutive sampling. Kriteria inklusinya adalah Ibu hamil yang sedang melakukan pemeriksaan ANC di Puskesmas Kuta Selatan dan bersedia menjadi responden. Kriteria eksklusinya adalah Ibu hamil yang tidak bisa membaca dan menulis.

\section{Tempat dan Waktu Penelitian}

Penelitian ini dilakukan di Puskesmas Kuta Selatan. Pengambilan data dilakukan selama 3 minggu.

\section{Instrumen dan Prosedur Pengukuran}

Pengumpulan data variabel kualitas pelayanan ANC dilakukan dengan kuesioner kualitas pelayanan ANC. Responden yang sesuai dengan kriteria sampel dan bersedia menjadi responden akan diberikan kuisioner setelah melakukan proses pemeriksaan antenatal. 
Ni Putu Mita Rahayu: Hubungan Kualitas Pelayanan ANC dengan Tingkat Kepuasan Ibu Hamil di Wilayah Kerja Puskesmas Kuta Selatan

\section{Analisa Data}

Pengolahan data dilakukan dengan tahap editing, coding, entry, cleaning dan tabulating. Analisis menggunakan uji Rank Spearman.

\section{HASIL PENELITIAN}

Hasil penelitian akan dijelaskan sebagai berikut:

\section{Tabel 1}

Karakteristik Ibu Hamil ( $=86)$

\begin{tabular}{lcc}
\hline $\begin{array}{l}\text { Karakteristik } \\
\text { responden }\end{array}$ & $\begin{array}{c}\text { Frekuensi } \\
\text { (f) }\end{array}$ & $\begin{array}{c}\text { Persentase } \\
(\%)\end{array}$ \\
\hline Pekerjaan Ibu & & \\
$\quad$ Buruh & 2 & 2,3 \\
Swasta & 32 & 37,2 \\
Wiraswasta & 22 & 25,6 \\
Pegawai & 6 & 7 \\
negeri & & \\
Tidak & 24 & 2,9 \\
bekerja & & \\
\hline Tingkat & & \\
Pendidikan & & \\
SD & 2 & 2,3 \\
SMP & 6 & 7 \\
SMA & 48 & 55,8 \\
Diploma & 11 & 12,8 \\
S1 & 19 & 22,1 \\
\hline Umur & & \\
Kehamilan & & \\
0-3 bulan & 8 & 9,3 \\
4-6 bulan & 58 & 67,4 \\
7-9 bulan & 20 & 23,3 \\
\hline Kunungan & &
\end{tabular}

\begin{tabular}{lll}
\hline $\begin{array}{l}\text { Kunjungan } \\
\text { Pemeriksa } \\
\text { Ibu Hamil }\end{array}$ & & \\
$\quad<3$ kali & 61 & 70,9 \\
$\quad>4$ kali & 25 & 29,1 \\
\hline Kualitas & & \\
Pelayanan & & \\
ANC & & \\
$\quad$ Baik & 14 & 16,3 \\
Cukup & 22 & 25,6 \\
$\quad$ Kurang & 50 & 58,1 \\
\hline Tingkat & & \\
Kepuasan Ibu & & \\
Hamil & & \\
$\quad$ Puas & 14 & 16,3 \\
$\quad$ Biasa & 19 & 22,1 \\
$\quad$ Tidak Puas & 53 & 61,6 \\
\hline
\end{tabular}

Berdasarkan Tabel 1. diketahui karakteristik berdasarkan pekerjaan ibu yang paling dominan adalah pekerja swasta sebanyak 32 orang $(37,2 \%)$. Dilihat dari tingkat pendidikan ibu paling dominan yaitu berpendidikan SMA sebanyak 48 orang $(55,8 \%)$. Berdasarkan umur kehamilan ibu yang paling dominan yaitu berumur 4-6 bulan sebanyak 58 orang $(67,4 \%)$. Berdasarkan untuk kunjungan periksa ibu hamil yang paling dominan melakukan pemeriksaan $<3$ kali sebanyak 61 orang $(70,9 \%)$. Sebagian besar responden memiliki kualitas pelayanan ANC yang kurang sebanyak 50 responden $(58,1 \%)$ dan sebagian besar responden memiliki tingkat kepuasan ibu hamil yang tidak puas sebanyak 53 responden $(61,6 \%)$.

\section{Tabel 2}

Hubungan Kualitas Pelayanan ANC Dengan Tingkat Kepuasan Ibu Hamil

\begin{tabular}{|c|c|c|c|c|c|c|}
\hline \multirow[b]{2}{*}{$\begin{array}{l}\text { Kualitas } \\
\text { Pelayan } \\
\text { an ANC }\end{array}$} & \multicolumn{3}{|c|}{ Tingkat Kepuasan } & \multirow[b]{2}{*}{$\begin{array}{l}\overrightarrow{0} \\
\stackrel{\overrightarrow{0}}{\overbrace{}^{0}}\end{array}$} & \multirow[b]{2}{*}{$\begin{array}{c}\mathrm{p}- \\
\text { value }\end{array}$} & \multirow[b]{2}{*}{$\mathrm{r}$} \\
\hline & 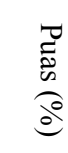 & 吕. & 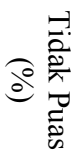 & & & \\
\hline Baik & 16,3 & 0 & 0 & 16,3 & \multirow{4}{*}{0,000} & \multirow{4}{*}{0,954} \\
\hline Cukup & 0 & 22,1 & 3,5 & 25,6 & & \\
\hline Kurang & 0 & 0 & 58,1 & 58,1 & & \\
\hline Total & 16,3 & 22,1 & 61,6 & 100 & & \\
\hline
\end{tabular}

Berdasarkan tabel 2. menyatakan responden bahwa kualitas layanan ANC kurang baik dengan tingkat kepuasan tidak puas sebanyak $58,1 \%$. Hasil analisa bivariat dengan menggunakan uji rank spearman untuk menganalisa hubungan kualitas pelayanan ANC dengan tingkat kepuasan ibu hamil diperoleh P-value $=0,000$ dengan ketentuan $\alpha=0,05$ atau $\mathrm{P}<0,05$ yang berarti Ha diterima, sehingga ada hubungan antara kualitas pelayanan ANC dengan tingkat kepuasan ibu hamil. Nilai $r$ korelasi koefisien $=0,954$ artinya tingkat kekuatan hubungan sangat kuat dan arah korelasi positif menunjukan semakin kurang kualitas pelayanan ANC maka semakin berkurangnya tingkat kepuasan pasien.

\section{PEMBAHASAN}

Penelitian ini sejalan dengan hasil penelitian Mursyida et al. (2012) menyatakan bahwa kualitas pelayanan ANC di Puskesmas Tanjung Kabupaten Sampang 
Madura baik dari aspek reliability dan tangible dan tidak baik dari aspek responsiveness, assurance dan empathy. Penelitian ini dilakukan pada ibu hamil dimana sebagian besar ibu hamil bekerja sebagai pekerja swasta $(37,2 \%)$ dan sebagian besar berpendidikan SMA $(55,8 \%)$. Hasil penelitian Mursyida et al. (2012) menunjukkan ibu hamil menganggap kualitas pelayanan ANC telah baik dari aspek tangible dan reliability tetapi terdapat ibu hamil yang menganggap kualitas pelayanan ANC tidak baik dari aspek emphaty, responsiveness dan assurance.

Penelitian ini juga sejalan dengan hasil Kahar et al. (2017) memberikan hasil serupa dengan penelitian ini dimana kualitas pelayanan kebidanan ANC tidak baik dari seluruh aspek kualitas pelayanan. Penelitian yang dilakukan oleh Kahar et al. (2017) menunjukkan hasil dengan karakteristik responden didominasi oleh pasien dengan pendidikan S1 (40,7\%) yang termasuk dalam pendidikan tinggi yang mampu untuk menilai kualitas pelayanan, pada penelitian ini daya tanggap dan pelayanan yang diberikan kepada ibu hamil masih sangat kurang seperti kurangnya memberikan senyum dalam melakukan pelayanan.

Peneliti berasumsi bahwa kualitas pelayanan ANC sebagian besar kualitas pelayanan yang kurang. Berdasarkan hasil karateristik responden seperti pekerjaan dan pendidikan memiliki pendidikan yang sebagian besar SMA dan ibu hamil yang bekerja sebagai pegawai swasta, karakteristik individu yang sebagian besar bekerja dan berpendidikan tinggi mampu memberikan penilaian mengenai kualitas pelayanan yang diberikan kepada dirinya. Hal ini sesuai dengan pendidikan SMA sebagian besar menilai kualitas pelayanan kurang sebanyak 31 ibu hamil $(36,0 \%)$ dan pekerjaan swasta sebagian besar mengatakan kualitas pelayanan ANC kurang sebanyak 20 ibu hamil $(23,2 \%)$. Berdasarkan observasi peneliti pegawai puskesmas yang kurang dalam memberikan perhatian saat memberikan pelayanan kepada ibu hamil juga yang membuat kualitas pelayanan ANC kurang.
Hasil tersebut menunjukkan bahwa sebagian besar ibu hamil tidak puas dengan pelayanan ANC. Hasil ini sejalan dengan penelitian yang dilakukan oleh Rifatrika (2016) bahwa sebanyak 19 ibu hamil $(45,2 \%)$ puas dan sebanyak 23 ibu hamil $(54,8 \%)$ tidak puas dengan palayanan ANC di Puskesmas Depok III. Hasil penelitian ini tidak sejalan dengan penelitian yang dilakukan oleh Mursyida et al. (2012) bahwa sebanyak 44 ibu hamil $(49,4)$ tidak puas dan sebanyak 45 ibu hamil $(50,6)$ puas dengan pelayanan ANC di Puskesmas Tanjung Kabupaten Sampang Madura.

Kepuasan pasien dipengaruhi oleh berbagai faktor, salah satunya dalah karakteristik pasien seperti pekerjaan dan pendidikan. Penelitian ini dilakukan pada ibu hamil dimana sebagian besar ibu hamil bekerja sebagai pekerja swasta $(37,2 \%)$ dan berpendidikan SMA (55,8\%). Penelitian ini menunjukkan bahwa ibu hamil yang memiliki pendidikan yang tinggi dapat memberikan jawaban tentang kepuasan selama pegawai puskesmas memberikan pelayanan. Hasil ini sejalan dengan penelitian Rifatrika (2016) hasil menyatakan bahwa sebagian besar ibu hamil tidak puas dengan pelayanan ANC. Penelitian tersebut dilakukan pada ibu hamil yang sebagian besar berpendidikan SMA $(54,8 \%)$ dan sebagian besar bekerja (61,9\%). Hasil menunjukkan ibu hamil merasa tidak puas dengan pelayanan yang terdapat dipuskesmas karena pelayanan yang diberikan kurang cepat dan kurangnya ada keramahtamahan dari petugas kepada ibu hamil sehingga ibu hamil lebih memilih untuk memeriksakan kandungan di tempat lain. Penelitian yang dilakukan oleh Mursyida et al. (2012) memberikan hasil yang berbeda dimana sebagian besar ibu hamil puas dengan pelayanan ANC. Penelitian tersebut dilakukan pada ibu hamil yang sebagian besar berpendidikan SMP $(40,5 \%)$ dan sebagian besar tidak bekerja $(71,9 \%)$. Hasil penelitian ini menunjukkan bahwa pendidikan sangat mempengaruhi ibu hamil untuk menilai pelayanan yang diberikan sehingga kurang puasnya ibu hamil tentang pelayanan ini dapat dilihat dari tindakan pegawai puskesmas dari melakukan pemeriksaan. 
Sebagian besar didapatkan tingkat kepuasan pasien rendah. Hal ini dipengaruhi oleh karasteristik responden adalah pendidikan dan pekerjaan. Pasien yang berpendidikan menengah yaitu lulusan SMA dan sebagian besar bekerja dapat memberikan penilaian terhadap pelayanan yang diberikan. Hal ini sesuai dengan ibu hamil yang berpendidikan SMA menyatakan tidak puas sebanyak 33 $(38,4 \%)$ dan ibu hamil yang bekerja swasta juga sebanyak 22 ibu hamil $(25,6 \%)$ menyatakan tidak puas selain itu umur kehamilan ibu yang berusia 4-6 bulan yang memeriksakan dirinya kepuskesmas menyatakan tidak puas sebanyak $32 \mathrm{ibu}$ hamil (37.2\%).

Terdapat korelasi positif menunjukan semakin kurang kualitas pelayanan ANC maka semakin berkurangnya tingkat kepuasan pasien. Hal ini sejalan dengan penelitian Kahar et al. (2017) bahwa kualitas pelayanan ANC berpengaruh signifikan terhadap kepuasan pasien. Kualitas pelayanan ANC yang rendah membuat pasien tidak puas dengan pelayanan ANC tersebut. Penelitian ini menunjukkan bahwa kurang puasnya ibu hamil didapatkan dari kualitas pelayanan yang diberikan dimana kurang senyum dan perhatian yang diberikan pegawai puskesmas membuat ibu hamil malas untuk memeriksakan kehamilan di puskesmas. Hasil ini didukung oleh Rahayu (2013) bahwa kurangnya tingkat kepuasan pelayanan ANC yang kurang, penelitian ini menyatakan disebabkan oleh kurangnya kemampuan pihak pemberi pelayanan untuk membantu merespon kebutuhan/keinginan konsumen. Penelitian Lupiyoadi (2013) menyatakan bahwa kualitas pelayanan yang baik mampu memenuhi harapan-harapan yang diinginkan atau diharapkan dari konsumen. Hal ini menunjukkan bahwa kualitas pelayanan yang semakin baik dapat memenuhi harapan dan keinginan dari konsumen sehingga kepuasan kepuasan yang semakin besar.

\section{KESIMPULAN \\ Implikasi}

Tingkat kualitas pelayaan ANC di Puskesmas Kuta Selatan, didapatkan sebagian besar dikategorikan kurang dan Tingkat kepuasan ibu hamil di Puskemas Kuta Selatan sebagaian besar dikategorikan tidak puas. Berdasarkan hasil tersebut diharapkan dukungan dari pihak suami dan keluarga, untuk memberikan dukungan serta peran dari petugas kesehatan untuk memberikan pengetahuan tentang di dalam mempersiapkan proses kehamilan dan melahirkan guna mencegah hal-hal yang membahayakan ibu dan janin.

\section{Keterbatasan}

Hasil penelitian ini menunjukkan bahwa kualitas pelayanan ANC kurang baik akan mempengaruhi ketidakpuasan ibu hamil dalam memeriksakan kehamilannya dipuskesmas kualitas pelayanan belum dapat memenuhi harapan dari yang diharapkan oleh pasien. Berdasarkan observasi bahwa lingkungan yang sempit dan kurang tanggapnya petugas dalam melakukan pelayanan membuat ibu hamil menunggu terlalu lama, jenuh dan bosan sehingga kondisi tersebut membuat pasien mempunyai kepuasan yang rendah terhadap kualitas pelayanan ANC yang diterimanya.

\section{DAFTAR PUSTAKA}

Aritonang, L. R. (2015). Kepuasan Pelanggan. Jakarta: Gramedia Pustaka Utama

Dinas Kesehatan Kabupaten Badung. (2017). Laporan Tahunan Dinas Kesehatan Provinsi Bali.

Haposanita, R., Jati, S. P., \& Suparwati, A. (2014). Hubungan Antara Persepsi Wanita Hamil Tentang Kualitas Layanan Antenatal dengan Kepuasan Wanita Hamil Di Pusat Kesehatan Kota Krobokan Semarang. Jurnal Kesehatan Masyarakat, 2(2), 156-161.

Hayuningsih, S., Mutika, W.T. (2018). Hubungan Antara Karakteristik Pasien Terhadap Kepuasan Pasien (Aspek Tangibles) Pada Pelayanan Antenatal Care Di Rumah Bersalin Citra Lestari Pabuaran Bojonggede Bogor Jawa Barat. Program Studi D III Kebidanan/ Program Diploma Kesehatan Universitas Gunadarma Jakarta. 3rd UGM Public Health Symposium. Yogyakarta, 8-9 May 2018. 
Ni Putu Mita Rahayu: Hubungan Kualitas Pelayanan ANC dengan Tingkat Kepuasan Ibu Hamil di Wilayah Kerja Puskesmas Kuta Selatan

Kahar, d. (2017). Pengaruh Persepsi Mutu Pelaanan Kebidanan Terhadap Kepuasan Pasien Rawat Inap Di RSUD Barru Sulawesi Selatan. Public Health Science Journal , 122-127.

Lupiyoadi, R. (2013). Manajemen pemasaran Jasa Berbasis Kompetensi (Edisi 3). Jakarta: Salemba Empat

Melay, S. R. (2013). Hubungan Kualitas Pelayanan Antenatal Care (ANC) Dengan Kepuasan Ibu Hamil Terhadap Pelayanan ANC Di Puskesmas Mergangsan. Jurnal Kesehatan Dan Kedokteran, 2(2), 1-13.

Mursyida, R.F., Mawarni, A., Agushybana, F.(2012). Kepuasan Ibu Hamil Dan Persepsi Kualitas Pelayanan Antenatal Care Di Puskesmas Tanjung Kabupaten Sampang Madura. Media Kesehatan Masyarakat Indonesia, Vol.11/No.2, Oktober 2012.

Nurpahmi, I., \& Emilia. (2015). Faktor-faktor Yang Behubungan Dengan Kepuasan Ibu Hamil Terhadap Kualitas Pelayanan Antenatal Care Di Puskesmas Kelurahan Cibubur Kecamatan Ciracas. Jurnal Ilmiah Kesehatan, 8(2), 35-40.

Rahayu, L. D. P., Fajarsari, D., \& Mastuti, S. (2013). Hubungan Kualitas Pelayanan Antenatal Care (ANC) Dengan Tingkat Kepuasan Ibu Hamil Di Puskesmas Karanganyar Kabupaten Purbalingga. Jurnal Ilmu Kesehatan, 3(2).

Kementerian Kesehatan RI. (2018). Riset Kesehatan Dasar (Riskesdas) : Hasil Utama. 